\title{
The Effect of Concept Mapping on Learning English Requests by Iranian High School Students
}

\section{Ali ZANGoei}

PhD Candidate, Faculty of Literature and Humanities, Hakim Sabzevari University Sabzevar, Irán

E-mail: zangoei.ali@gmail.com

\author{
Seyed Mohammad Reza Amirian
}

Assistant Professor, Faculty of Literature and Humanities, Hakim Sabzevari University, Sabzevar, Irán

E-mail: sm.amirian@hsu.ac.ir

\section{THE EFFECT OF CONCEPT MAPPING ON LEARNING ENGLISH REQUESTS BY IRANIAN HIGH SCHOOL STU- DENTS}

ABSTRACT: The Research into interlanguage pragmatics has prominent significance nowadays. Due to severe negative consequences of failure in performing and interpreting speech acts such as request, the present study investigated the effect of concept mapping on learning English requests by Iranian high school students. To this aim, 72 intermediate male English students (ranging in age from 15 to 18 ) that were in two intact groups from a city in northeastern Iran, voluntarily took part in the study. Data for this study were collected using English Test- Beginner (proficiency test) and Multiple Discourse Completion Task Test (MDCT) The results indicated there was a statistically significant difference between the request speech act knowledge of those learners who were taught requests through concept mapping and those who were taught traditionally. The results of the current study have important implications for syllabus designers and material developers particularly in EFL contexts.

KEY WORDS: Interlanguage pragmat ics; Concept map; English request; Written Discourse Completion Task Test; Multiple Discourse Completion Task Test.

SUMMARY: 1. Introduction. 2. Review of Literature 3. Method 3.1 Participants 3.2 Instruments 3.2.1 English Test Beginner (Proficiency Test) 3.2.2 Written Discourse Completion Task (WDCT) 3.3 Procedure 4. Results. 5. Discussion 6. Conclusion.

Fecha de Recepción

Fecha de Revisión

Fecha de Aceptación

Fecha de Publicación
EL EFECTO DEL MAPEO CONCEPTUAL EN EL APRENDIZAJE DE SOLICITUDES DE INGLÉS POR PARTE DE ESTUDIANTES DE SECUNDARIA IRANÍES

RESUMEN: La investigación en la pragmática entre lenguas tiene un significado prominente en la actualidad. Debido a las graves consecuencias negativas del fracaso en la realización e interpretación de actos de habla como la solicitud, el presente estudio investigó el efecto del mapeo de conceptos en el aprendizaje de solicitudes de inglés por parte de estudiantes iranies de secundaria. Para este objetivo, 72 estudiantes de inglés varones intermedios (de 15 a 18 años de edad) que formaban parte de dos grupos intactos de una ciudad en el noreste de Irán, participaron voluntariamente en el estudio. Los datos para este estudio se recopilaron utilizando la Prueba de inglés para principiantes (prueba de competencia) y la Prueba de tarea de finalización de múltiples discursos (TCMD). Los resultados indicaron que hubo una diferencia estadisticamente significativa entre el conocimiento del acto de habla de la solicitud de los alumnos a quienes se les enseñó las solicitudes a través del mapeo de conceptos y los que se les enseñó tradicionalmente. Los resultados del estudio actual tienen implicaciones importantes para los diseñadores de programas de estudio y los desarrolladores de materiales, particularmente en contextos de EFL.

PALABRAS CLAVES: Pragmática interlenguaje; Mapa conceptual; Solicitud de ingles Prueba de tarea de finalización del discurso escrito; Prueba de tarea de finalización de múltiples discursos

SUMARIO: 1. Introducción. 2. Revisión de la literatura 3. Método 3.1 Partici-pants 3.2 Instrumentos 3.2.1 Prueba de inglés - Principiante (Prueba de competencia) 3.2.2 Tarea de finalización del curso escrito (WDCT) 3.3 Procedimiento 4. Resultados. 5. Discusión 6. Conclusión.

$09 / 09 / 2017$

$23 / 06 / 2019$

$10 / 07 / 2019$

01/12/2019 DOI: http://dx.doi.org/10.25267/Pragmalinguistica.2019.i27.20
EFFET DE LA CONCEPTION SUR LES DEMANDES D'ENSEIGNEMENT DE L'ANGLAIS DES ÉTUDIANTS IRANIENS

RÉSUMÉ: La recherche sur la pragmatique interlangue a une importance prééminente de nos jours En raison des graves conséquences négatives de l'échec lors de l'exécution et de l'interprétation d'actes de langage tels que ceux demandés, la présente étude a examiné les effets de la cartographie conceptuelle sur l'apprentissage des demandes en anglais des lycéens iraniens. À cette fin 72 étudiants anglais masculins d'âge appartenant à deux groupes intacts d'une ville du nord-est de l'Iran on participé volontairement à l'étude. Les données de cette étude ont été recueillies à l'aide de l'anglais Test Débutant (test de compétence) et du test de fin de discours multiple (MDCT). Les résultats ont indiqué qu'il existait une différence statistiquement significative entre la connaissance des actes de parole des apprenants à qui les demandes étaient traitées via le mappage de concepts et celle des apprenants de manière traditionnelle. Les résultats de la présente étude ont des implications importantes pour les concepteurs de programmes et les concepteurs de matériaux, en particulier dans les contextes EFL.

MOTS CLÉS: Pragmatique interlangue Carte conceptuelle; Demande en anglais; Test de tâche de complétion du discours écrit; Test de tâche d'achèvement de discours multiples

SOMMAIRE: 1 . Introduction. 2 Examen de la littérature 3. Méthode 3.1 Participants 3.2 Instruments 3.2.1 Test d'anglais - Débutant (test de compétence) 3.2.2 Tâche d'achèvement du cours écrit (WDCT) 3.3 Procédure 4. Résultats. 5. Discussion 6. Conclusion. intermédiaire (âgés de 15 à 18 ans) 


\title{
The Effect of Concept Mapping on Learning English Requests by Iranian High School Students
}

\author{
Ali Zangoei \& Seyed Mohammad ReZA AMIRIAN
}

\section{INTRODUCTION}

Recently, the study of pragmatic competence in an L2 has received noticeable attention by second language acquisition (SLA) researchers (Kim, 2016). According to Yule (1996, p. 3), "pragmatics is concerned with the study of meaning as communicated by a speaker (or a writer) and interpreted by a listener (or reader)." It has come to be applied to the study of language from the point of view of the users, especially in the choices they make, the constraints they encounter in using language in social interaction, and the effects their use of language has on the other participants in an act of communication (Kasper $\&$ Rose, 2001). In the same line, Beltrán-Planques and Querol-Julián (2018) consider pragmatic competence as one of the scope of pragmatics which is broadly defined as "the ability to communicate appropriately in a social context" (p.1).

In SLA research, there is an assumption that language learners in learning an L2 create a language system called "interlanguage" by formulating an internalized system based on available linguistic elements in their native language and the target language. Yet, there are some elements in their interlanguage which do not represent their origin in either linguistic source (Gass \& Selinker, 1994). According to Kasper and Blum-Kulka (1993), interlanguage pragmatics (ILP) is the study of non-native speakers' use and acquisition of linguistic behavior patterns in an L2.

Studies of ILP have followed the lead of previous work in cross-cultural pragmatics and interlanguage research to compare data sets between L1, L2 and interlanguage (Kasper, 1998). Research in the area of ILP aims broadly at understanding how nonnative speakers of a language acquire and develop socio-cultural skills in order to communicate their meanings in the second language appropriately and adequately (Naiditch, 2006).

In ILP as well as cross-cultural pragmatics, speech acts represent the most widely-investigated aspect of linguistic action (Blum-Kulka, House \& Kasper, 1989). Regarding the investigative objects of some of the more recent ILP studies, the speech acts that have received the most attention are requests, apologies, compliments, and increasingly, refusals (e.g., Barron, 2019, Blum-Kulka, et al., 1989; Kasper \& Blum-Kulka, 1993; Jeon \& Kaya, 2006; Takahashi, 2010; Taguchi, 2015, 2017). Also, Norouzian and Eslami (2016) regard speech acts, conversational routines, and implicatures as the prime focus of ILP studies.

As Sifianou (1992) points out, speech act theory is directly related to the issue of politeness. When making a request, the requester needs to use various politeness strategies, such as different degrees of directness and 
external modifications, so the request will be achieved. In daily communication, people may give a threat to another individual's self-image, or create a "face-threatening act". These acts impede the freedom of actions (negative face), and the wish that one wants be desired by others (positive face) - by either the speaker, or the addressee, or both. Requests potentially threaten the addressee's face because "they may restrict the addressee's freedom to act according to his/her will" (Holtgraves 2002, p. 40).

With the recognition of the significance of speech acts, plenty of techniques for teaching and learning them have come out. Most of the techniques and strategies to the teachability of pragmatic components particularly on the part of speech acts have mainly accounted for the relative effectiveness of different types of pragmatic instruction/mediations or the priority of two approaches of explicit and implicit instruction over one another (Ajabshir, 2019; Derakhshan \& Arabmofrad, 2018; Derakhshan \& Zangoei, 2014; Emadi, 2015; Hashemi Shahraki, Ketabi, \& Barati, 2015; Jernigan, 2012; Kargar, Sadighi, \& Ahmadi, 2012; Rose, 2005; Sykes, 2018; Taguchi, Xiao, \& Li, 2016; Tateyama, 2001).

Concept mapping is a relatively new technique which is helpful for learning in L2 classes. Concept maps, in Novak and Canăs's (2006, p. 17) view, are "graphical tools for categorizing and representing knowledge." They consist of concepts which are usually enclosed in "circles or boxes of some type and relationships between concepts indicated by connecting or linking two concepts or words on line, referred to as linking words or linking phrase" (ibid.). As a result of the limitations and challenges involved in dealing with teaching sociopragmatic and pragmalinguistic aspects of speech acts as essential components of pragmatic competence especially in the foreign language context, the use of authentic, ever-developing techniques like concept mapping have gained considerable attention these days. Based on the available literature in the following section, concept mapping can be used as a learning strategy and it can be employed by the teachers in the classroom for more effective teaching. However, so far only a few studies have touched upon using concept mapping in learning speech acts. Based on the aforementioned discussions, one of the most important factors investigated in this study is the role of concept mapping strategy in Iranian English as a foriegn language (EFL) learners' ILP development where the students don't have a lot of opportunities or abilitities to interact with English native speakers.

In spite of the importance of request speech act and also the significance of concept mapping in language teaching and learning, few studies worldwide and nationwide namely in Iranian EFL context have been conducted in order to highlight these important aspects of language pedagogy. Therefore, the present study aims at investigating the effect of concept mapping on learning English requests by Iranian high school students. 


\section{REVIEW OF LITERATURE}

Ausubel (1968) believes that learning is a continuous process of building, expanding, and modifying old concepts over time as new relationships are introduced and linked with previous concepts. However, cognitive processing theory endorses that for retaining information, learners should pay attention to it and encode it into long-term memory by linking new information to existing information and making a series of perceptual networks or schemata (Gredler, 2001). Concept mapping promotes this process because it assists the learner to make sense of concepts by linking new concepts with prior existing concepts in the memory and then categorizing them hierarchically to form an integrated, coherent framework of the material learned. This is accepted to encourage meaningful learning (Novak, 1990).

Concept mapping promotes meaningful learning by assisting learners to recognize, clarify, and categorize the abstract concepts and relationships through the information being processed via visually presenting them in an almost easily comprehended format. Concept mapping encourages meaningful learning by starting active interactions of learners with the information being processed and by linking what is being processed in the working (or short-term) memory to what they have already known (their prior knowledge) in the long-term memory (Novak, 1990). Taricani (2002) maintains that one of the greatest significance of concept mapping is that they require learners to deal consciously and explicitly with what is normally an implicit activity. In the same line, Morfidi, Mikropoulos, and Rogdaki, (2018) hold that concept mapping, as a learning strategy, improves comprehension, memory, and encourages meaningful learning.

Recently, concept maps have broadly been the research basis in different scientific fields, and studies have depicted the positive effect of concept maps on meaningful learning (Novak \& Cañas, 2006, Novak, 2010). Also, Kalhor and Shakibaei (2012) investigated the effect of teaching English reading comprehension to Iranian students through concept mapping. Data analysis indicates that concept mapping technique has a noteworthy effect on English reading comprehension.

Liu, Chen, and Chang (2010) explored the effect of creating concept maps with the help of computer on English reading comprehension of English bachelor's students in Taiwan in which English was an L2. The result of this study depicted that not only concept map strategy enhances reading comprehension, but also it strengthens the application of other reading comprehension strategies .Dias (2010) utilized concept maps to enhance English reading comprehension of bachelor's students in which English was an L2. The findings of the study indicated that concept map is an effective strategy to strengthen reading comprehension. Increasing their independence in application of knowledge organizing methods, the students learned how to make use of tools to create concept maps. 
Another study was carried out by Lee and Cho (2010) to explore the application of group concept map on the writing skills of Korean university students. They came to the conclusion that the concept map extremely promotes the students writing skill. Talebinezhad and Mousapour Negari (2007) explored the effectiveness of concept mapping as a learning strategy on students' self-regulation. The findings showed that students obtained higher self-regulation as the result of concept mapping strategy teaching. In a case study by Ojima (2006), the effect of concept map as a pre-task on three Japanese students writing skill was explored. The result of the study indicated that concept mapping optimizes learners' English writing skill on the basis of complexity. Abu Nada (2008) conducted a research about the effect of using concept maps on achieving English grammar among the ninth graders in Gaza governorate. The study revealed statistically significant differences in the ninth grades' achievement of English grammar due to the method in favor of concept map start. Maleki and Dabbaghi (2013) worked on the applicability of drawing concept maps on reinforcing reading comprehension of students at some high schools. The findings indicated that treatment had positive impacts on reading comprehension of the students. In another study, Chularut and DeBecker (2004) investigated the effectiveness of concept mapping used as a learning strategy with students in ESL classroom. The findings indicated a statistically significant interaction of time, method of instruction, and level of English proficiency for self-monitoring, self-efficacy, and achievement. For all four outcome variables, the concept mapping group demonstrated significantly greater gains from pre-test to post-test than the individual study group.

To illuminate the use of concept map in language learning/teaching and as a sort of self-experienced action research, the authors have applied concept mapping as a rich source of strengthening the taught material in skill teaching course to Teaching English as a Foreign Language (TEFL) students at Hakim Sabzevari University, Iran. Whatever follows is the process of preparing a concept map to teach the chapter of Listening derived from two books of Second Language Learning and Language Teaching (Cook, 2008) and Methodology in Language Teaching (Richards \& Renandya, 2002):

Constructing the concept map for teaching listening and other skills went through the phases of brainstorming which included classifying facts, terms, and ideas in the source under study that were in anyway associated with the topic and then writing them down, organizing which consisted of generating groups and sub-groups of related concepts and then creating hierarchies for the clusters and rearrange the items and add the new ones, layout which was a trying phase to reach the best arrangement of the interrelationships and interconnections among concepts with reliable hierarchies, Linking when lines were used with arrows which can initiate or end on significant concepts and also to link and join the relationship between connected concepts, and finalizing the concept map which was the last phase for transforming the concept map into a long-lasting constructive 
form with appropriate colors, fonts, shapes, border thickness and a related title to convey the concepts to have a profound process of learning/teaching.

In conclusion, concept mapping has been frequently utilized in the studies to investigate its effectiveness on several aspects of language skills and sub-skills, nonetheless, to the best knowledge of the researchers, if no, scant studies have capitalized upon the application of concept mapping in teaching these ubiquitous components of pragmatic competence namely speech acts in different contexts particularly Iranian EFL context. In other words, teaching speech acts through concept mapping has received limited attention in Iran and few research, if any, has been done practically. In this regard, the current study is an attempt to cast more light on ILP development of Iranian learners of English to fill the aforementioned gaps.

However, like any other investigation conducted so far, the current study is not exempt from limitations which in turn contain recommendations for future research on concept mapping strategy. They are enumerated as follows: First, the participants of the study could be chosen from different English proficiency levels and also from different English institutes in different cities which might enhance the reliability and validity of the results of the research. Second, concept mapping strategy could be applied to teach other language skills and sub-skills to other EFL learners. Nevertheless, the present study is directed by the following research question:

Is there any statistically significant difference between the request speech act knowledge of those learners who are taught through concept mapping and those who are taught traditionally?

\section{METHOD}

\subsection{PARTICIPANTS}

The participants of this study were seventy-two male EFL students of grade 2 from two high schools in Gonabad, Iran, who voluntarily took part in an adjunct English course to develop their English proficiency in the specialized aspects of English language namely pragmatics and the knowledge of request speech act in particular. The age range of participants were 15 to 18 years old with intermediate level of English language proficiency and with Persian as their first language. The participants were two intact groups that were chosen based on convenience or opportunity sampling. Additionally, the participants were ensured that the result of the study would be used only for research intentions. Also, a verbal consent was taken from all participants before the start of the study.

\subsection{INSTRUMENTS}

The instruments employed in this study are as follows: (1) An English Test- Beginner (proficiency test) for homogenizing the participants' level of 
language proficiency, and (2) A Written Discourse Completion Task Test (WDCT) for assessing the participants' pragmatic competence in the pre and posttest.

\subsubsection{ENGLISH TEST - BEGINNER (PROFICIENCY TEST)}

Before starting to implement the treatment, the researchers administered "English Test - Beginner" Proficiency Test developed by Bertrand (1994) in order to take action to ensure that all the learners are at the same level of language proficiency. The test includes 100 multiple choice items on vocabulary, grammar, pronunciation, and reading. The participants were given appropriate allotted time to respond the questions. It is worth mentioning that in spite of this fact that the proficiency in the language is not always correlated to the pragmatic competence, the relationship between the level of language proficiency and ILP is relatively direct and positive (Ellis, 2019; Garcia, 2004; Naoko, 2013; Soo, 2013; Xiao, 2015, Xu, Case \& Wang, 2009; Yang, 2015).

In order to compute the reliability of the use of the proficiency test, the researchers administered the test to the pilot group of thirty-eight students in other schools of Gonabad whose students were at the same level (intermediate) with the participants of this study. The researchers used the Kuder and Richardson Formula 21 (KR-21) to calculate the internal consistency of the test. This test checks the internal consistency of measurements with dichotomous choices. It is appropriate when each question is dichotomous (either right or wrong) and a correct question scores 1 while an incorrect question scores 0 . The reliability index for the "-English Test - Beginner" Proficiency Test in this study was found to be 0.81 . Regarding the test's content validity, five experts' comments were sought. The experts were selected based on their experience in teaching different general and special English courses to the students of TEFL at Hakim Sabzevari University. Each strongly confirmed the appropriateness of the test regarding the general objective of measuring beginners' English proficiency.

\subsubsection{WRITTEN DISCOURSE COMPLETION TASK (WDCT)}

In order to measure the students' knowledge of the request speech act, the researchers employed a WDCT and gathered written responses from the learners. The test consisted of 23 situations adopted from Derakhshan (2014) and designed to extract different aspects of the speech act of request. There was an empty slot for the speech act response in the beneath of each situation. According to Brown (2001) "a WDCT is a kind of pragmatic instrument that requires the students to read a written description of a situation (including such factors as setting, participant roles, and degree of imposition) and asks them to write what they would say in that situation" (p. 301). 
The following example is a request speech act of WDCT which was used to elicit the participants' pragmatic competence of request speech act:

Phil: Hi, Lilly. It's Phil.

Lilly: Hi, Phil. What's up?

Phil: Not much, but I was wondering if I could ask you for a favor.

Lilly: Mmm, maybe. Try me.

Phil: Well, I have to go out of town for a few days next week.

Lilly: Aha.

Phil: Could I leave Polly with you while I'm gone?

Lilly: Polly? Who's Polly?

Phil: You know, Polly, my bird.

Lilly: Oh, yeah. I forgot, your bird. I don't know Phil. I really don't like birds very much. They're messy. They make a lot of noise, and ...

Phil: Oh, no, not Polly. She's really a great bird. She's really clean and very quiet. She won't bother you, I promise.

Lilly: Oh, alright, I'll do it.

Phil: Thanks, I really appreciate it.

Phil says "Could I leave Polly with you while I'm gone?" What is another way to say this?

Your Answer:

It should be mentioned that each of the WDCT such as the above mentioned was used in order to elicit the participants' responses in the pre and posttest. The reason for using the WDCT was to obtain good hints on the part of request speech act to be worked on during the instruction sessions by the researchers. However, to compare the participants' performance in the pre and posttest, they were taken to the corresponding Multiple-choice Discourse Completion Test (MDCT) of each of the request speech act WDCT by four options in the pre and posttests. The rationale behind this process was to obtain the quality of objectivity and achieve the generalizability of the results. Moreover, triangulation of data in educational and social science research serves different sources of collecting data to increase the credibility and validity of the results (Kern, 2018). In MDCT, the test-taker involves to read a written description of a situation and select from the several given options what would be most suitable in that situation based on pragmatic factors such as power, social status, and level of imposition, in contrast to a WDCT that requires the test-taker to write what they would say in that situation (Brown, 2001). The MDCT format of the mentioned example included the same stem but with four options:

Phil says "Could I leave Polly with you while I'm gone?" What is another way to say this?

a. Please take care of Polly while I'm away.

b. You have to take care of Polly while I'm away. 
c. I was wondering if you'd mind taking care of Polly while I'm away.

d. Would you please take care of Polly while I'm away?

The reliability of MDCT was computed by its post-test reliability. The researchers also performed KR-21 formula for the computation of the internal consistency of the test. The reliability index for the MDCT of the study was 0.79 . In addition, for checking content validity, three pragmatic experts who had taught different courses of pragmatics, evaluated each item with its options and had comments on the correct option and the distractors. The interrater reliability between scorers was computed. The interrater reliability of the three scorers were computed and they were fairly consistent in their whole evaluations; at the significance level of .05, the correlation was .77.

\subsection{PROCEDURE}

In order to conduct the research, two intact groups that were selected based on convenience sampling were used to compare the effectiveness of concept mapping on learning English requests. One class was chosen as the control group $(\mathrm{N}=38)$ and the other as the experimental group $(\mathrm{N}=34)$. The "English Test - Beginner" Proficiency Test was administered in the first session to ensure the homogeneity of the students in terms of language proficiency. Then, in another day, the WDCT and the MDCT of English requests were given as the pre-test to the participants of both groups before starting the instruction. As mentioned before, the request MDCT was given to the students as the pretest and the posttest to compare the pragmatic competence of English requests before the instruction and after the instruction.

Afterwards, the researchers started to teach to both groups in the session after the pretest administered. English requests were taught to the two groups in different ways; the experimental group received concept mapping technique for teaching requests and other one received traditional ways for the same requests. Each group received nine sessions of instruction (each session thirty minutes). The process of English request teaching was different for two groups so that for, the students in the control group were presented an audio file containing a request speech act for three times, then they were asked to think about the situation and express their ideas about each turn of the conversation to clarify the difficult lexical terms and expressions. After that, the transcript of the conversation followed by a question was distributed between the students and they were required to write their responses in each situation. Finally, the students read their answers and each answer was compared with others.

The process of teaching requests in the experimental group was similar to the control group, but teaching the same English requests were upgraded by concept mapping at the end of each session. In other words, the students in experimental group listened to an audio file for three times, then they had 
a discussion on special words and structures to disambiguate the uncertainties and misunderstandings on the listening. Subsequently, they answer the question at the end of each transcript of the conversation. Next, the students were completely briefed about the concept map which was provided at the back of each of the conversation transcript sheet. They were required to identify each of the effective component in a request speech act socially and appropriately like the topic of the request, distance, power, degree of imposition and so on which were connected to each other around the key word through lines. Finally, the researchers as the instructors of the course and the students had a comprehensive discussion on each part of the concept map.

The number of the requests taught was the same for both groups. They were nineteen listening conversations featuring speech act of request which were extracted by the researchers from the textbooks of Four Corners Series (Richards \& Bohlke, 2011), American English File Series (Oxenden, LathanKoenig, \& Seligson, 2008), English Result Series (Hancock, \& McDonald, 2009), and Touchstone Series (McCarthy, McCarten, \& Sandiford, 2005) taught in the language institutes in Iran. Each conversation included pragmalinguistic and sociopragmatic features of the speech act of request. The researchers discussed these features through the concept maps to make the students aware of the idiosyncrasies of each request in the experimental group, while the control group was instructed thorough typical way without concept map. A sample of a concept map followed at the end of each conversation and was applied as the treatment of the experimental group is as follows:

Listen to the conversation. What things does Kate ask Ruth to do for her? Ruth: Oh, hi, Kate. What's up?

Kate: Hi, Ruth. Listen, I'm going away this weekend. Can you do me a favor?

Ruth: Sure. What do you need?

Kate, Can you feed my cat, please?

Ruth: No problem. I'll feed her. Is that all?

Kate: Well, could you please get my mail, too?

Ruth: Sure. I could do that for you. I'll put it on your kitchen table. Anything else?

Kate: If you don't mind, there's one more thing.

Ruth: What's that?

Kate: I'm getting back at 11:00 on Sunday night. Would you mind picking me up at the airport?

Ruth: Actually that's kind of late for me. I need to get up early on Monday morning. I have an important business meeting then. Sorry.

Kate: No, no, that's fine. It's asking a lot, I know.

Ruth: Do you think you can ask someone else?

Kate: I'1l just take a taxi. It's not a big deal. 
Why can't Ruth pick Kate up? Your Answer:

Now number the best choice for each of the request expression in the following concept map.

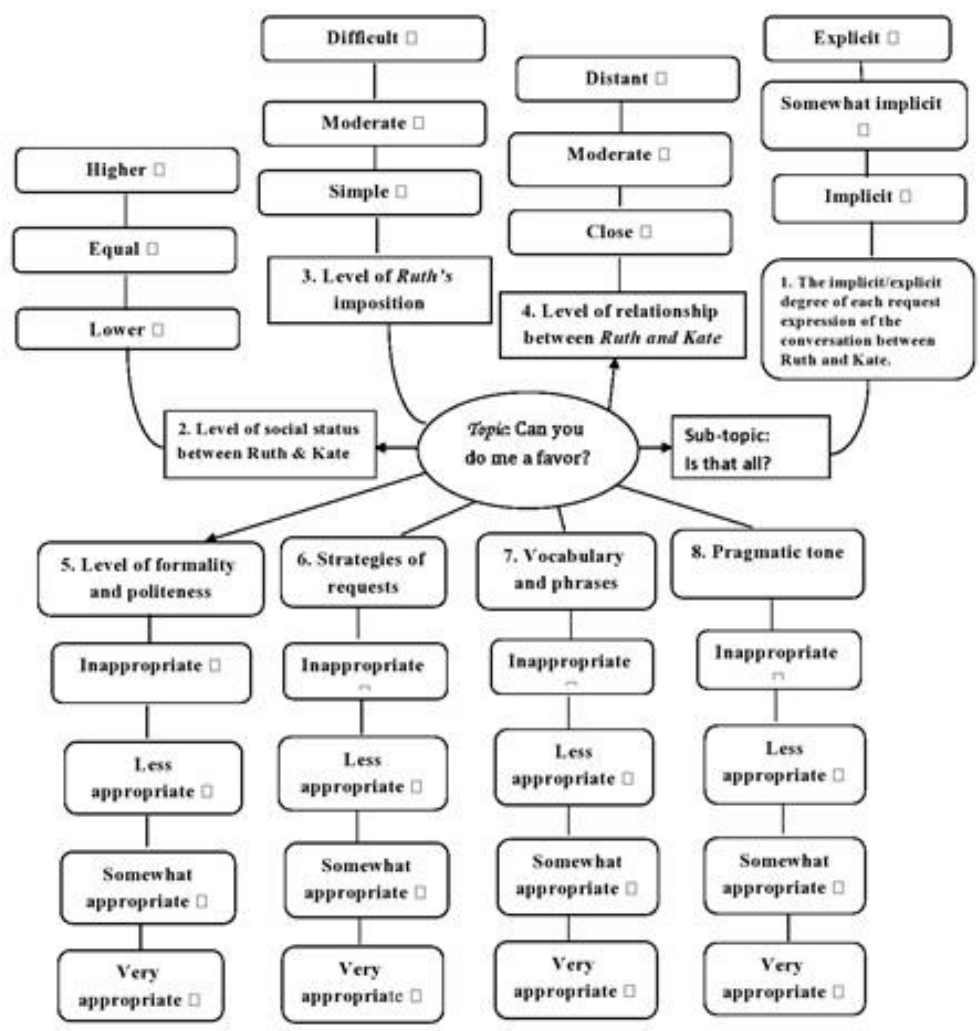

Request Expression 1: Can you do me a favor?

Request Expression 2: Can you feed my cort, please?

Request Expression 3: Well, could you please get my mall, too?

Request Expression 4: If you don't mind, fhere's one more thing

Request Expression 5: Would you mind picking me up at the eirport?

Figure 1: A request concept map applied in pragmatic course in the experimental group

As indicated in Figure 1, the students in the experimental group were required to identify each aspect of the request speech act such as the level of formality and politeness by numbering the request expression in a continuum from inappropriate to very appropriate in each session. Then, the 
researchers and the students had a comprehensive discussion on each aspect to compromise into the appropriateness/inappropriateness of each discussed request expression.

It should be mentioned that designing and developing each component of the request concept map was based on Brown and Levinson (1978, 1987) theory of politeness that believe some speech acts such as requests and refusals are inherently positive or negative. Some acts like requests have been considered impolite and consequently they are categorized into face-threatening-acts (FTAs) which need mitigating by linguistic or other politeness strategies (Brown, 1987). Face in this theory associates a kind of public image in which a conversation is effective only when the face of the interlocutors are maintained by each other. Thus, face is "something that is emotionally invested, and that can be lost, maintained, or enhanced, and must be constantly attended to in interaction" (Brown \& Levinson, 1987, p. 61). Based on this theory, the success of an interaction is highly affected by sociopragmatic factors such as the interactants' power, social distance, and degree of imposition and so on. So, this framework was an inspiring point to develop and apply the concept map to be tried as a new strategy in teaching pragmatics because it takes into account several factors of an effective communication in different contexts.

The researchers taught one or two requests in each session of 30 minutes to the both groups but in different way for each one. The experimental and control groups were instructed for 9 sessions. At the end of the instruction, the MDCT posttest that was the same as the pretest was given to the both groups. Having gathered the data collection, Statistical Package for Social Sciences (SPSS 22) program as an appropriate statistical test were used to analyze and compare the performance of two groups of the control and experimental before and after the instruction.

\section{REsults}

To make certain that all the learners are homogeneous in terms of language proficiency, the researchers administered the "English Test - Beginner" Proficiency to both groups at the very beginning. After collecting the data, the descriptive statistics was produced by the statistical SPSS program. The descriptive statistics of proficiency test for both groups are shown in Table 1.

\begin{tabular}{|c|c|c|c|c|c|c|}
\hline & groups & $\mathrm{N}$ & Mean tic & Std. & $\begin{array}{c}\text { Devia- } \begin{array}{c}\text { Std. } \\
\text { Mean }\end{array} \\
\end{array}$ & Error \\
\hline profi- & control & 38 & 42.66 & 9.78 & 1.59 & \\
\hline ciency & $\begin{array}{l}\text { experi- } \\
\text { mental }\end{array}$ & 34 & 42.12 & 10.13 & 1.74 & \\
\hline
\end{tabular}

Table 1: Descriptive statistics for proficiency test of control and experimental group 
As shown in Table 1, for the control group, the mean score was 42.66 and the SD was 9.78 and for the experimental group, the mean score was 42.12 and the SD was 10.13. Since the means cannot show the actual difference between the groups, an Independent Samples $t$-test was manipulated as presented in Table 2 .

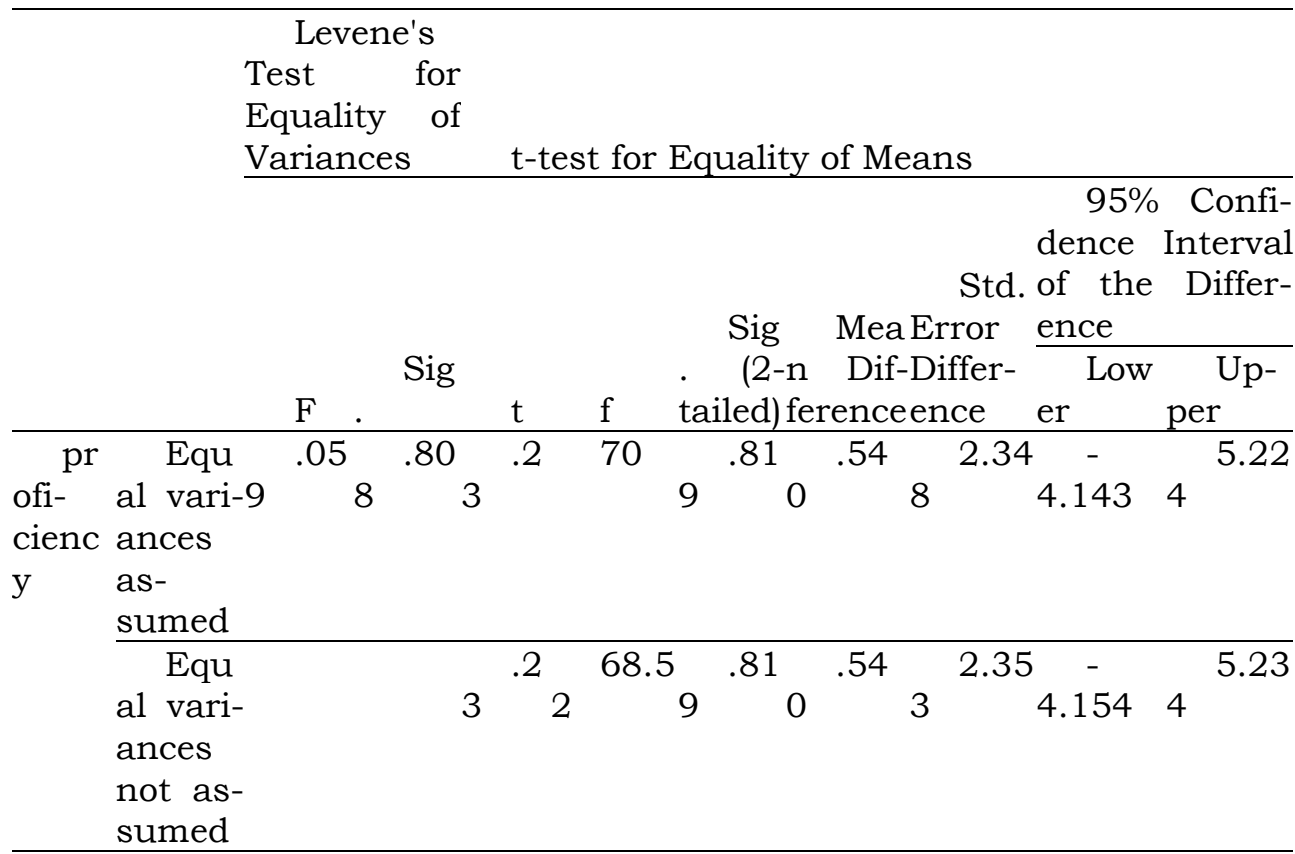

Table 2: Independent samples t-test: control group proficiency test vs. experimental group proficiency test

As Table 2 displays, there was no statistical difference between the two groups, $t(70)=0.23, p=0.05$. As a result, no significant difference was detected between the learners' mean scores in the proficiency test within the control and experimental groups; therefore, the participants of the control and experimental groups were most probably homogeneous.

In the following lines, the descriptive statistics (mean, standard deviation) of the pre-test scores of both groups are shown in Table 3.

\begin{tabular}{cccccl}
\hline & groups & $\mathrm{N}$ & Mean & Std. Deviation & Std. Error Mean \\
\hline $\begin{array}{c}\text { pre- } \\
\text { test }\end{array}$ & control & 38 & 3.34 & .966 & .157 \\
& $\begin{array}{c}\text { experi- } \\
\text { mental }\end{array}$ & 34 & 3.62 & .922 & .158 \\
\hline
\end{tabular}

Table 3: Descriptive statistics for experimental vs. control groups' pretest score 
For the control group, the mean score was 3.34 and the SD was .96 and for the experimental group, the mean score was 3.62 and the SD was .92. Apparently, there was no significant difference between the means of the control and experimental groups. To make sure whether there is any significant difference between the mean scores of the control and experimental groups, the researchers ran an independent sample $t$-test. Table 4 demonstrates the result of the independent samples $t$-test.

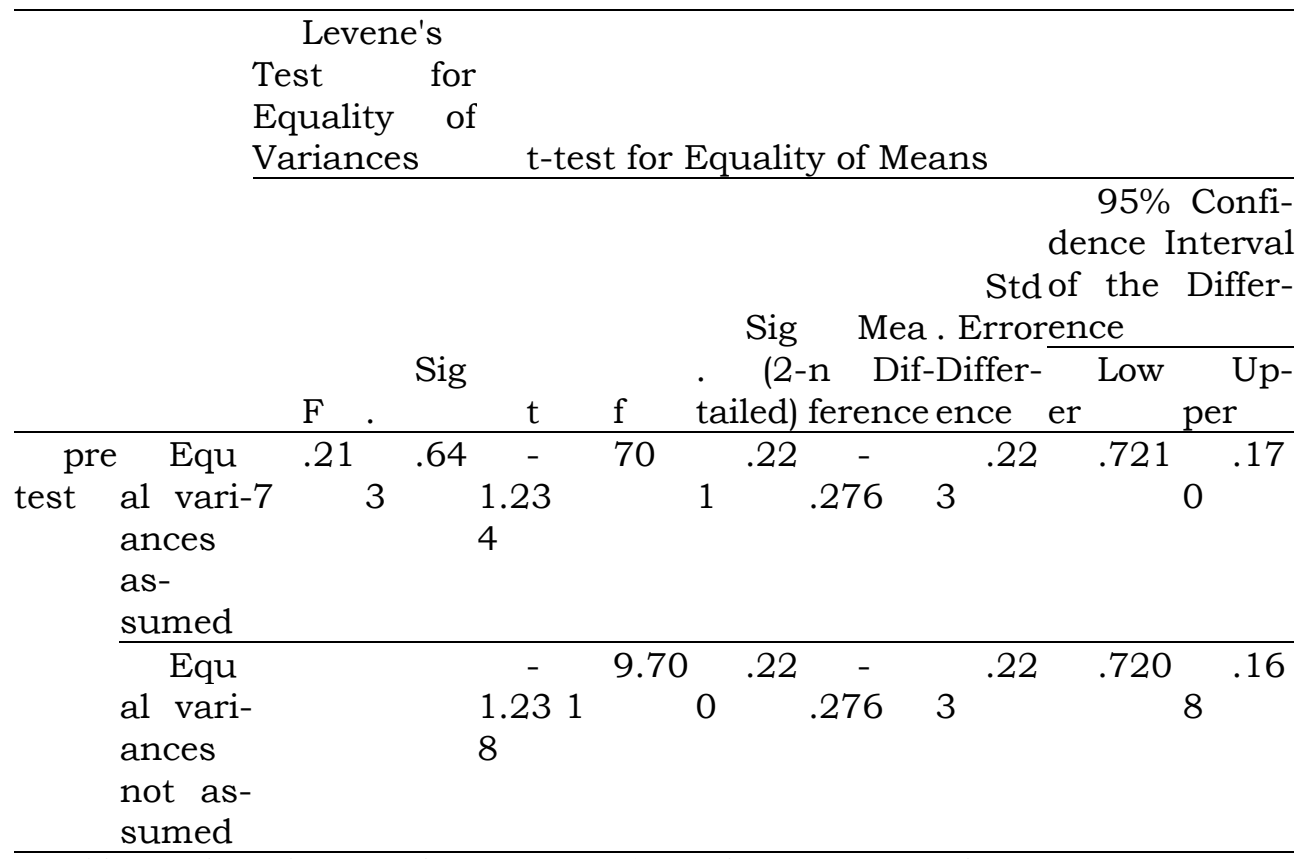

Table 4. Independent samples t-test: experimental group vs. control group pretest scores

As it is demonstrated in Table 4, there was no statistical difference between groups, $t(70)=-1.23, p=0.05$. It can be claimed that there was no significant difference between the experimental and control groups' pre-test scores; therefore, the two groups were most probably homogenous in terms of request speech act background knowledge.

Table 5 indicates the descriptive statistics (mean, standard deviation) of the post-test scores of both control and experimental groups.



Table 5. Descriptive statistics for experimental vs. control groups' posttest score 
As it is seen in Table 5, for the control group, the mean score was 10.92 and the SD was 3.45 , and for the experimental group, the mean score was 14 and the SD was 3.50. Probably, concept mapping has been more effective in learning request speech act than the traditional method.

To make certain whether the difference between the mean scores of the experimental and control groups was significant, an independent samples ttest was run. Table 6 demonstrates the result of the independent samples ttest.

\section{Levene's}

Test for

Equality of

Variances $\quad$ t-test for Equality of Means

95\% Con-

Std fidence Inter-

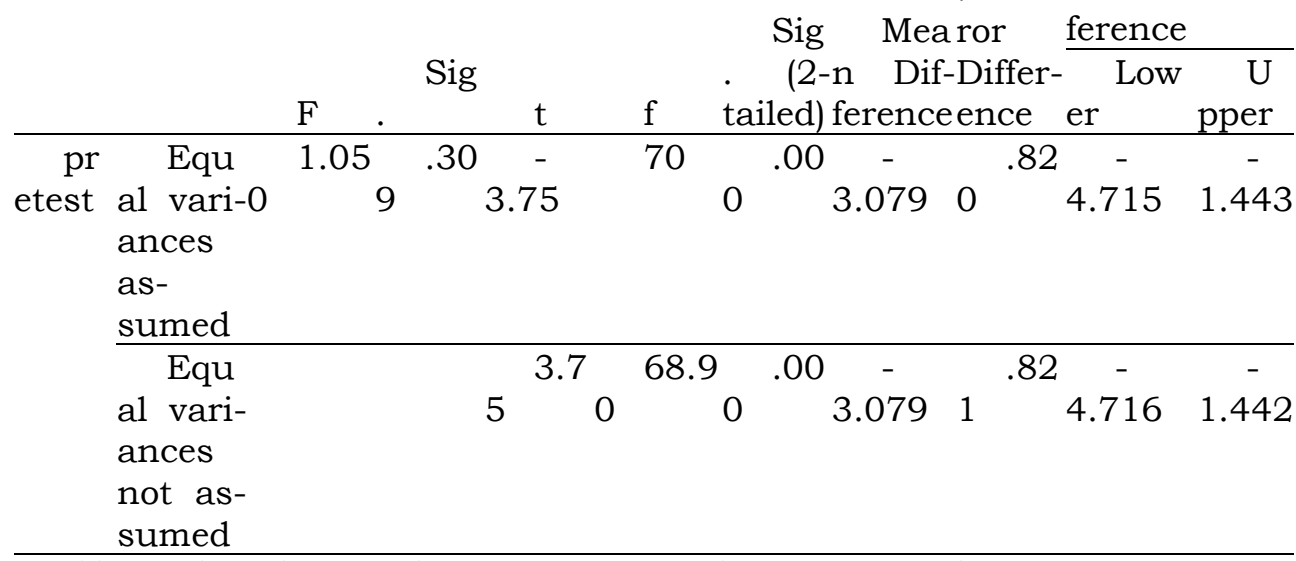

Table 6. Independent samples t-test: experimental group vs. control group posttest scores

As it is displayed in Table 6, there was a significant difference between the experimental and control groups, $t(70)=-3.75, p=0.05$. It can be stated that the null hypothesis is rejected. It was concluded that there is a statistically significant difference between those learners who were taught request speech act through concept mapping $(M=14, S D=3.50)$ and those who were taught traditionally $(M=10.92, S D=3.45)$. Therefore, concept mapping strategy outweighed the traditional one in learning request speech act.

\section{Discussion}

In the following, the research question will be presented and discussed thoroughly. 
Is there any statistically significant difference between the request speech act knowledge of those learners who are taught through concept mapping and those who are taught traditionally?

The above research question was answered on the basis of the students' performance on 23 items of MDCT. As it was indicated in Tables 3, 4, 5 and 6 , participants' performance in the experimental group showed a significant ILP development of the participants. In other words, the results showed a statistically significant difference between the request speech act knowledge of those learners who were taught requests through concept mapping and those who were taught traditionally. Therefore, the experimental group instructed by concept mapping outperformed the control group with traditional one in learning English requests.

The above findings regarding the effects of concept map strategy are consistent with the results of some previous studies. Kalhor and Shakibaei (2012) investigated the effect of teaching English reading comprehension to Iranian students through concept mapping. Data analysis indicates that concept mapping technique has a noteworthy effect on English reading comprehension. The findings of the present study are also compatible with the study of Liu, Chen, and Chang (2010) who explored the effect of creating concept maps with the help of computer on English reading comprehension of English bachelor students in Taiwan in which English was an L2. The result of study this depicted that not only concept map strategy enhances reading comprehension, but also it strengthens the application of other reading comprehension strategies .

Moreover, the result of this study is in line with a study by Lee and Cho (2010) who explored the application of group concept map on writing skill of Korean university students. They came to a conclusion that the concept map extremely promotes the students writing skill. Likewise, Abu Nada (2008) conducted a research about the effect of using concept maps on achieving English grammar among the ninth graders in Gaza governorate. The study revealed statistically significant differences in the ninth grades' achievement of English grammar due to the method in favor of concept map strategy, which is consistent with the findings of the present study.

The findings of this study might be due to some reasons. One reason might be owing to the fact that concepts activate learners in the process of learning. Based on Auzubel's (1968) meaningful learning theory, concept map plays the role of an advance organizer. The advance organizer presented by teacher activates the mind of the students through connecting the prior knowledge to new information. Another reason might be due to the fact that concept map works as a cognitive tool. Therefore, in line with information processing theory (Rumelhart, McClelland, \& PDP Research Group, 1988, as cited in Kriegeskorte, 2015) which cogently accentuates the role of reviewing, expanding, and organizing instructional materials in transferring information, presenting the concept map in a class as a cognitive tool can 
provide a mind path to transfer information effectively and improve the mind status, as well (Kalhor \& Shakibaei, 2012).

\section{Conclusion}

The present study supports the idea that making use of concept mapping tools can extend and enrich students' learning. Therefore, concept mapping would be very useful in EFL classrooms as a learning tool. In addition, trying the use of various ways in developing L2 learning in general and ILP on the part of speech acts has been suggested; likewise, using concept map may raise an increasing amount of interests by EFL teachers who are seeking and applying new instructional methods in their classes to have an effective process of language teaching/learning. Another important implication for language teachers is that working with concept maps in each class can be much more time-saving and practical leading to better performance as what has been indicated in the present study, because in the process of working with concept maps, most of the linguistic redundancies are eliminated through nods, links, and cross-links.

Taking advantage of concept mapping strategy, it can be helpful where there are not any instruments or facilities for teachers to teach speech acts meaningfully such as multimedia material except coursebooks. In other words, encouraging students to draw graphical maps for learning speech acts can be applicable where students don't have real chance or ability to interact with native speakers, teachers or other students through English speaking skill. Teachers may enhance the achievement as well as the selfefficacy of their EFL students by familiarizing them with the concept mapping strategy .

Students may optimize their learning by adopting concept mapping as a learning strategy. Since concept mapping is a student-directed strategy that does not heavily rely on teacher-fronted lecturing, it is easily adopted by users. Furthermore, concept mapping is simple and flexible enough to be useful in a variety of learning settings like Iran. For the sake of lacking a communicative approach incorporated in high school textbooks particularly in EFL contexts like Iran, students do not necessarily learn high-demanding aspects of second language such as speech acts. In this case, the students prefer to translate every English speech act into their native language ignoring important components of pragmalinguistics and sociopragmatics in each interaction that in turn, leads to several misinterpretations and failures in communication (Eslami-Rasekh \& Eslami-Rasekh, 2008).

Consequently, encouraging students to extract speech acts from different instructional textbooks as a task, presenting them in some forms like circles or rectangles and link them to their pragmatic features by some lines in a communicative environment may direct them to use concept mapping as a learning strategy to regulate their learning. In the same line, as Chularut and DeBecker (2004) have rightfully stated, learners might optimize their 
learning by using concept mapping as a learning strategy. It provides learners with a better learning environment and makes them play various roles as, thinkers, problem solvers, and researchers. Such roles help them learn and use English language in different situations more easily. Thus, for L2 learners to be strategic and also aware of their strategies for being able to handle the linguistic barriers to communicate effectively, they need to be instructed on how to make use of concept mapping strategy and how to develop concept maps. However, constructing efficient concept maps requires close cooperation, practice, and patience between teachers and students.

\section{REFERENCES}

ABU NADA, MK (2008): The effect of using concept maps on achieving English grammar among ninth graders in Gaza governorate (Unpublished M. A. thesis, The Islamic University of Gaza.).

AJABSHIR, ZF (2019): "The effect of synchronous and asynchronous computer-mediated communication (CMC) on EFL learners' pragmatic competence", Computers in Human Behavior, 92, pp. 169-177.

AUSUBEL, D. P. (1968): Educational psychology: A cognitive view. New York: Holt, Rinehart and Winston. Bertrand, W. (n. d.). English Test - Beginner. (Available in: "http:// www.ispilled thebeans.com/exercises/PDF / exercisestestbeginner, (pdf)").

BARRON, A. (2019): "Using corpuslinguistic methods to track longitudinal development: Routine apologies in the study abroad context", Journal of Pragmatics, 146, pp. 87-105.

BELTRÁN-PLANQUES, V. \& QUEROL-JULIÁN, M. (2018): "English language learners' spoken interaction: What a multimodal perspective reveals about pragmatic competence System, 77, pp. 80-90.
BERTRAND. E. (1994): Student assessment and evaluation. In B. Harp (ed.), Assessment and evaluation for student centered learning Norwood, MA; Christopher-Gordon, pp. 27-45.

BLUM-KULKA, S., HOUSE, J. \& KASPER, G. (eds.) (1989): Cross cultural pragmatics: Requests and apologies. Norwood: Ablex Publishing.

BROWN, J. D. (2001): Pragmatics tests: Different purposes, different tests. In K. R. Rose \& G. Kasper (eds.), Pragmatics in language teaching, New York: Cambridge University Press, pp. 301-325.

BROWN, P. \& LEVINSON, S. C. (1978): "Universals in language use: Politeness phenomena”. In E. N. Goody (ed.), Questions and politeness: Strategies in social interaction, Cambridge: Cambridge University Press, pp. 56-289.

BROWN, P. \& LEVINSON, S. C. (1987): Politeness: Some universals in language usage. Cambridge: Cambridge University Press.

COOK, V. (2008): Second language learning and language teaching. 4th edn. London: Hodder education. 
CHULARUT, P. \& DEBACKER, T. K. (2004). "The influence of concept mapping on achievement, self-regulation, and self-efficacy in students of English as a second language", Contemporary Educational Psychology, 29(3), pp. 248-263.

DERAKHSHAN, A. (2014): The effect of consciousness-raising videodriven prompts on the comprehension of implicatures and speech acts (Unpublished $\mathrm{PhD}$ dissertation, Allameh Tabataba'i University, Tehran, Iran.)

DERAKHSHAN, A. \& ARABMOFRAD, A. (2018): "The Impact of Instruction on the Pragmatic Comprehension of Speech Acts of Apology, Request, and Refusal among Iranian Intermediate EFL Learners", English Teaching \& Learning, pp. 1-20.

DERAKHSHAN, A. \& ZANGOEI, A. (2014): "Video-Driven Prompts: A viable pragmatic consciousness-raising approach in EFL/ESL classrooms", International Journal of Language Learning and Applied Linguistics World (IJLLALW), 5(2), pp. 368-380.

DIAS, R. (2010): "Concept map: a strategy for enhancing reading comprehension in English as L2. Proc. of Fourth International Conference on Concept Mapping". J. Sánchez, A. J. Cañas, J.D. Novak, Eds. Viña del Mar, Chile.

ELLIS, R. (2019): “Towards a modular language curriculum for using tasks", Language Teaching Research, 23(4), pp. 454-475.

EMADI, M. (2015): Dynamic assessment of listening comprehension in foreign language learning (Unpublished MA thesis). Golestan Science and Research Branch, Islamic Azad University, Gorgan, Iran.
ESLAMI, Z. R. \& ESLAMI-RASEKH, A. (2008). "Enhancing the pragmatic competence of nonnative English-speaking teacher candidates (NNESTCs) in an EFL context", Investigating pragmatics in foreign language learning, teaching and testing, 30(2), pp. 178-197.

GARCIA, P. (2004): "Pragmatic comprehension of high and low level language learners", TESLEJ, 8(2), pp. 1-15.

GASS, S. \& SELINKER, L. (1994): Second language acquisition: An introductory course. Hilldale. NI: Lawrence Erlbaum.

GREDLER, M. E. (2001): Learning and instruction: Theory into practice (4th ed.). Upper Saddle River, NJ: Merrill Prentice Hall.

HANCOCK, M. \& MCDONALD, A. (2009): English Result Series. Oxford: Oxford University Press.

HASHEMI SHAHRAKI, S., KETABI, S. \& BARATI, H. (2015): "Dynamic assessment in EFL classrooms: Assessing listening comprehension in three proficiency levels", International Journal of Research Studies in Education, 4(3), pp. 73-89

HOLTGRAVES, T. (2002): Language as social action. London: Lawrence Erlbaum Associates.

JEON, E. H. \& KAYA, T. (2006): "Effects of L2 instruction on interlanguage pragmatic development", In J.M. Norris \& L. Ortega (eds.), Synthesizing research on language learning and teaching Amsterdam: John Benjamins, pp. 165-211.

JERNIGAN, J. E. (2012): "Output and English as a second language pragmatic development: The effectiveness of output-focused 
video-based instruction", $\mathrm{Ca}$ nadian ELT Journal, 5(4), pp. 2-14.

KALHOR, M. \& SHAKIBAEI, G. (2012): "Teaching reading comprehension through concept map", Life Science Journal, 9(4), pp. 725-731.

KARGAR, A., SADIGHI, F. \& AHMADI, A. R. (2012): "The Effects of collaborative translation task on the apology speech act production of Iranian EFL learners", The Journal of Teaching Language Skills (JTLS), 4 (3), pp. 47-78.

KERN, F. G. (2018): "The trials and tribulations of applied triangulation: weighing different data sources", Journal of Mixed Methods Research, 12(2), pp. 166-181.

KASPER, G. (1998): "Interlanguage pragmatics.", in H. Byrnes (ed.) Learning foreign and second languages: Perspectives in research and scholarship, New York: Modem Language Association of America, pp. 183208.

KASPER, G. \& BLUM-KULKA, S. (1993): Interlanguage pragmatics, New York: Oxford University Press.

KASPER, G. \& ROSE, K. R. (2001): "Pragmatics in language teaching", in K. R. Rose \& G. Kasper (eds.), Pragmatics in language teaching, Cambridge: Cambridge University Press, pp. 29.

KIM, H. (2016): "An Investigation into EFL Learners' Perception towards L2 Pragmatic Instruction", Theory and Practice in Language Studies, 6(3), pp. 452-462.

KRIEGESKORTE， N. (2015): “Deep neural networks: a new framework for modeling biological vision and brain information processing", Annual review of vision science, 1, pp. 417-446.

LEE, Y. \& CHO, S. (2010): Concept mapping strategy to facilitate foreign language writing: A Korean application (Retrieved December 3, 2010 from http://aatk.org/html).

LIU, P. L., CHEN, C. J. \& CHANG, U. J. (2010): "Effects of a computer-assisted concept mapping learning strategy on EFL college students' English reading comprehension", Computers \& Education, 54, pp. 436445.

MALEKI, M. \& DABBAGHI, A. (2013): "The Influences of concept mapping strategy on reading comprehension of those students challenging in studying invalid books at some high schools", MJAL, 5(2), pp. 101127.

MORFIDI, E., MIKROPOULOS, A. \& ROGDAKI, A. (2018): "Using concept mapping to improve poor readers' understanding of expository text", Education and Information Technologies, 23(1), pp. 271-286.

NAIDITCH, F. (2006): The pragmatics of permission: A study of Brazilian ESL learners (Doctoral Dissertation). Available from ProQuest Dissertations and Theses database. (UMI No. 3215491)

NAOKO, T. (2013): "Production of routines in L2 English: Effect of proficiency and study abroad experience", System, 41(1), pp. 109-121.

NOROUZIAN, R. \& ESLAMI, $Z$. (2016): "Critical perspectives on interlanguage pragmatic development: An agenda for research", Issues in Applied Linguistics, 20, pp. 25-50.

NOVAK, J. D. (1990): Concept maps and Vee diagrams: Two metacognitive tools to facilitate 
meaningful learning. Instructional Science, 19, pp. 29-52.

NOVAK, J. D. (2010): "The universality and ubiquitousness of concept maps. Proc. Of Fourth International Conference on Concept Mapping”. J. Sánchez, A. J. Cañas, J. D. Novak, Eds. Viña del Mar, Chile.

NOVAK, J. D. \& CAŇAS, A. J. (2006): The theory underlying concept maps and how to Construct them (It is available in: http: / / cmap.ihmc.us/Publications/ResearchPapers/Theory C maps/TheoryUnderlyingConceptMaps.htm).

OJIMA, M. (2006): “Concept mapping as pre-task planning: A case study of three Japanese ESL Writers", System, 34(4), pp. 566-585.

OXENDEN, C., LATHAN-KOENIG, C. \& SELIGSON, P. (2008): American English file series. Oxford: Oxford University Press.

RICHARDS，J. C. \& BOHLKE，D. (2011): Four Corners Series. Cambridge, UK: Cambridge University Press.

RICHARDS, J. C. \& RENANDYA, W. A. (eds.). (2002): Methodology in language teaching: An anthology of current practice. Cambridge university press.

ROSE, K. R. (2005): “On the effect of instruction in second language pragmatics", System, 33 (3), pp. 385-399.

MCCLELLAND, J. L. \& RUMELHART, D. E. (1988): "A simulationbased tutorial system for exploring parallel distributed processing", Behavior Research Methods, Instruments, $\&$ Computers, 20(2), pp. 263275.

SIFIANOU, M. (1992): Politeness phenomena in England and
Greece: A cross-cultural perspective. Oxford: Clarendon Press.

SOO, J. Y. (2013): "Measuring syntactic complexity in L2 pragmatic production: Investigating relationships among pragmatics, grammar, and proficiency", System, 42, pp. 270287.

SYKES, J. M. (2018): "Interlanguage Pragmatics, Curricular Innovation, and Digital Technologies", calico journal, 35(2), pp. 120.

TAGUCHI. N. (2015): 'Instructed pragmatics at a glance: Where instructional studies were, are, and should be going", Language Teaching, 48, pp. 1-48.

TAGUCHI, N., XIAO, F. \& LI, S. (2016): "Development of pragmatic knowledge in L2 Chinese: Effects of intercultural competence and social contact on speech act production in a study abroad context", Modern Language Journal, 100, pp. 775-796.

TAGUCHI, N. (2017): "Interlanguage pragmatics". In A. Barron, P. Grundy \& G. Yueguo (eds.), The Routledge Handbook of Pragmatics. Oxford/New York: Routledge, pp. 153-167.

TAKAHASHI, S. (2010): “Assessing learnability in second language pragmatics", in A. Trosborg (ed.) Handbook of Pragmatics: Pragmatics across Languages and Cultures. Berlin: Mouton de Gruyter, pp. 391-421.

TALEBINEZHAD， M. R. \& MOUSAPOUR NEGARI, G. (2007): "The Effect of explicit teaching of concept mapping in expository writing on EFL students' selfregulation", The Linguistics Journal, 2(1), pp. 69-90.

TARICANI, E. M. (2002): Effects of the level of generativity in concept 
mapping with knowledge of correct response feedback on learning (Unpublished doctoral dissertation, Pennsylvania State University, University Park, Pa.).

TATEYAMA, Y. (2001): "Explicit and implicit teaching of pragmatics routines: Japanese sumimasen", In K.R. Rose \& G. Kasper (eds.), Pragmatics in language teaching (pp. 200222). Cambridge University Press, Cambridge.

XIAO, F. (2015): "Proficiency effect on L2 pragmatic competence", Studies in Second Language
Learning and Teaching, 5(4), pp. 557-581.

XU, W., CASE, R. E. \& WANG, Y. (2009): "Pragmatic and grammatical competence, length of residence, and overall L2 proficiency", System, 37(2), pp. 205-216.

YANG, Q. (2015): "An Investigation of the Non-English Majors' Pragmatic Competence", Journal of Language Teaching and $\mathrm{Re}$ search, 6(6), pp. 1289-1296.

YULE, G. (1996): Pragmatics, Oxford: Oxford University Press. 